I. Nazarenko,

Doctor of Economic Sciences, Professor of the Department of accounting

and taxation, Sumy national agrarian university, Sumy

ORCID ID: 0000-0003-0874-199X

Zhou Yalian,

master's degree student, Sumy national agrarian university, Sumy

ORCID ID: 0000000248986898

DOI: $10.32702 / 2306-6814.2020 .21-22.43$

\title{
PROBLEMS AND IMPROVEMENT MEASURES IN FINANCIAL MANAGEMENT OF SMALL AND MEDIUM-SIZED PRIVATE ENTERPRISES IN ZHEJIANG PROVINCE
}

\author{
I. М. Назаренко, \\ А. е. н., професор кафедри обліку і оподаткування, \\ Сумський національний аграрний університет, м. Суми \\ Чжоу Ялянь, \\ магістр, Сумський національний аграрний університет, м. Суми
}

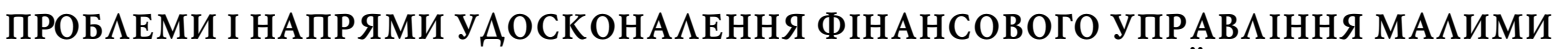

ТА СЕРЕАНІМИ ПРИВАТНИМИ ПІАПРИЄМСТВАМИ В ПРОВІНЦІЇ ЧЖЕЦЗЯНГ

The operating and development environment of small and medium private enterprises in Zhejiang has undergone major changes. Under the trend of fierce market competition and continuous economic development, some of the disadvantages and drawbacks of private small, medium and micro enterprises are constantly exposed. Among them, the financial management of enterprises is particularly prominent. The purpose of writing a scientific article is to analyze the existing problems of financial management of small and medium enterprises in China, as well as to identify priority strategic management measures, the implementation of which will promote the development of business entities. This article analyzes the problems in the financial management of private small and medium-sized enterprises, mainly due to poor financing ability; business operators lack financial risk management awareness; financial management is weak and financial systems are not sound; investment is lacking in science. Problems existing in financial management of private small and medium enterprises in Zhejiang: private small and medium enterprises have limited capital strength and lack of capital becomes their development bottleneck; private enterprises have weak awareness of financial risks; the financial management mode is rigid, and the quality of enterprise personnel is uneven.

Small and medium private enterprises must actively adapt to changes and innovate financial management. Only by further strengthening financial management and optimizing the implementation of management measures can the scientific rationality of private small and medium enterprises in the market development be ensured. Enterprises need optimize financial management models. 
Середовище функціонування малих та середніх приватних підприємств у провінції Чжецзянг суттєво змінюється. В умовах жорсткої ринкової конкуренції та трансформації економічних відносин виникають фактори, які здійснюють негативний вплив на розвиток приватних малих, середніх підприємств. Однією з найбільш актуальних проблемє управління фінансами підприємств. Метою написання наукової статті є аналіз чинних проблем управління фінансами приватних малих та середніх підприємств у Китаї, а також визначення пріоритетних стратегічних заходів управління, реалізація яких сприятиме розвитку суб'єктів господарювання. У статті аналізуються проблеми фінансового управління приватними малими та середніми підприємствами в Китаї, акцентується увага на фінансовій спроможності підприємств, а також визначено, що суб'єкти господарювання не мають необхідних навичок щодо управління фінансовими ресурсами, ризиками, відповідно, фінансовий менеджмент є недосконалим, фінансова система - не надійною, в науковій сфері недостатньо коштів.

Проблеми, що існують у фінансовому управлінні приватними малими та середніми підприємствами в провінції Чжецзянг такі: приватні малі та середні підприємства мають обмежений розмір капіталу, а відсутність капіталу стає їх слабким місцем для розвитку; приватні підприємства не усвідомлюють фінансові ризики; режим фінансового управління жорсткий, а працездатність персоналу підприємства нерівномірна; відсутність потужних фінансових можливостей управління, внутрішньої системи фінансового контролю.

Малі та середні приватні підприємства повинні активно адаптуватися до змін та впроваджувати інновації в управління фінансами. За допомогою вдосконалення фінансового управління та оптимізації впровадження управлінських заходів можна забезпечити раціональний розвиток приватних малих, середніх підприємств. Підприємствам також потрібно постійно оптимізувати моделі управління фінансами.

Key words: financial management, private enterprises, small and medium-sized enterprises, problem, countermeasure.

Ключові слова: фінансовий менеджмент, приВатні підприємстВа, малі та середні підприємстВа, проблема, протидія.

\section{INTRODUCTION}

From the perspective of the role and significance of small and medium-sized private enterprises, as an important subject of the market, it is of great significance to the development of China's economy.

Zhejiang province as China's private economy is a very active, coastal export-oriented region.Its development plays a huge role in economic take-off, promoting the development of Zhejiang economy from poverty to prosperity. From this point of view, small and mediumsized private enterprises are facing financial management problems, which have a significant impact on the whole economic and social stability of Zhejiang province.

We know that financial management is an economic management that organizes financial activities and deals with financial relations, and it is an integral part of enterprise management.

Therefore, strengthening the financial management of small and medium-sized private enterprises can reduce the financial risk to the maximum extent and improve the market competitiveness of enterprises, which is an impor- tant aspect of corporate governance of modern enterprises and also a necessary means to ensure the healthy and steady development of enterprises.

\section{LITERATURE REVIEW}

The following scientists have devoted their scientific works to the issue of enterprise management in China: Wu Yajie, Zhang Qihui, Hande Karadag, Wang Zhanxiang, Zhu Shaodong, He Xin, Zhang Xuxia, Ren Weijie, Cheng Lingli, Yang Sijing, Zuo Qian, Li Songlin and others.

These scientists have made a significant contribution to the development of the management process by enterprises, but the problems are relevant today and require further research.

\section{THE PURPOSE OF THE ARTICLE}

The purpose of writing a scientific article is to analyze the existing problems of financial management of small and medium enterprises in China, as well as to identify priority strategic management measures, the implementation of which will promote the development of business entities. 


\begin{tabular}{|c|}
\hline $\begin{array}{l}\text { PROBLEMS EXISTING IN FINANCIAL MANAGEMENT OF } \\
\text { PRIVATE SMALL AND MEDIUM ENTERPRISES IN ZHEJIANG }\end{array}$ \\
\hline $\begin{array}{l}\text { Private small and medium enterprises have limited capital strength and } \\
\text { lack of capital becomes their development bottleneck }\end{array}$ \\
\hline Private enterprises have weak awareness of financial risks \\
\hline $\begin{array}{l}\text { The financial management mode is rigid, and the quality of enterprise } \\
\text { personnel is uneven }\end{array}$ \\
\hline $\begin{array}{l}\text { Lack of strong financial management ability, lack of internal system and } \\
\text { lack of financial supervision }\end{array}$ \\
\hline Decision makers are very haphazard and investment is not scientific \\
\hline $\begin{array}{l}\text { Unreasonable allocation of financial personnel and lack of profession } \\
\text { knowledge of financial personnel }\end{array}$ \\
\hline
\end{tabular}

\section{Figure 1. Problems existing in financial management of private small and medium enterprises} in Zhejiang

\section{THE MAIN RESULTS OF THE RESEARCH}

In recent years, small and medium-sized enterprises have played an important role in the economic development in China.

Wu Yajie scholars believe that at present, there are many problems in small and medium-sized private enterprises, and financial problems are the focus of many discussions. The characteristics of small and medium-sized private enterprises result in the strategic diversity of solving these problems. Small and medium-sized private enterprises need to strengthen the study of financial strategies and apply them to the actual financial work of enterprises, which has become an important work content of the financial department at present [1].

Scholar Zhang Qihui believed that the key point for private small and micro enterprises to survive and continue to develop and grow is to do a good job in enterprise financial management. In view of the financial management problems of small and medium-sized enterprises, this paper analyzes the company's financial management situation from three aspects of investment, risk and financing, analyzes the company's financial situation, and puts forward solutions [2].

European and American experts and scholars generally pay more attention to the financial management of small and medium enterprises, and their focus is more novel. For example, the British Ouyang used the method of case analysis, analyzes a large number of cases, points out the basic steps and development strategies of small and medium-sized investment enterprises in overseas investment and listing, and puts forward a new enterprise financing management model, which is of great pioneering significance. In addition, scholars in China's listed private investment companies in the enterprise financial management, financial collectivization of private enterprises, financial management of enterprise information, and other aspects, have also had considerable in-depth research results.

Hande Karadag indicate that the small and mediumsized enterprises are facing many new challenges, and these problems directly caused by "poor financial management" is the main cause of the failure of small and medium-sized enterprises [3].

Small and medium-sized enterprises in Zhejiang province develop in rural collective commerce, urban collective commerce, private enterprise, and urban and rural collective commerce and other emerging non-stateowned economy. Compared with large enterprises, small and medium-sized enterprises have narrow scope of financial management activities, and small capital flow and stock. In addition, many small and medium-sized enterprises are "family" of the enterprise, and based on relative fundraising is given priority to, and give priority to with folk loan, generally on a smaller scale, low cost, USES the internal relatives management, financial decision-making highly centralized control, resulting in overall financial management confusion, lack of accounting basis work, lack of risk control system, and so on and so forth. To save costs, most companies have reduced the number of accountants, and many have even given jobs that should be done by one person to three, from finance to accounting to bank staff. Some private enterprises also have the provisions of enterprise management and the corresponding financial system, but in the specific operation because it is difficult to strictly grasp the actual death of the system and provisions, so that the enterprise in the specific operation in name only [4].

The boss of the positioning of the finance department in enterprise is still in the previous accounting, bookkeeping, etc., and are influenced by family management and financial member overall quality is not high, and most financial sector due to its attention, lead to the financial department didn't really play an irreplaceable role in the process of development of enterprise. The assessment system is not perfect, everything follows the will of the manager to implement management, financial decision-making control is highly centralized. The financial management system cannot provide guidance and standard for financial management activities, and the financial management of small and medium-sized enterprises is mostly contingent management system. At the present 


\begin{tabular}{|l|l|} 
Strengthen cooperation with financial institutions, improve \\
credit awareness, and solve financing problems through \\
multiple channels.
\end{tabular}

Figure 2.Suggestions on financial management of private small and medium enterprises in Zhejiang province

stage, the connotation of financial management of small and medium-sized enterprises presents a basic state of expansion, and the effectiveness of traditional financial management ideas, models and specific strategies keeps declining. Therefore, the improvement of financial management is also a practical problem faced by many small and medium-sized enterprises in the process of operation and development [7].

Problems existing in financial management of private small and medium enterprises in Zhejiang (figure 1).

Private small and medium enterprises have limited capital strength and lack of capital becomes their development bottleneck. Small and medium-sized enterprises have less registered capital and limited capital power. Many small and medium-sized enterprises are in the stage of development. During this period, the capital demand is the largest needed in the enterprise production cycle, and the lack of capital is the bottleneck of enterprise development. The reason why small and medium enterprises are having difficulty in getting loans is that even when the state eases lending and credit growth, their difficulties have not improved. Private enterprises have weak awareness of financial risks. Zhejiang private enterprises are always operating in high risk areas. Due to the small scale of small and medium-sized enterprises, insufficient financial resources, human resources, capital and other reasons, managers do not pay enough attention to financial management, do not establish financial risk awareness, lack of risk awareness, lack of risk prediction can not be timely to deal with, not ready. As a result, the company is unable to timely deal with financial risks that may occur at any time. Due to lack of experience and preparation, it is difficult to resist risks and lack of effective measures to reduce losses. This suggests the following:excessive debt, long-term bond investment, single investment method, lack of strong financial management ability [8].

Many small and micro enterprises do not have a special financial personnel (this kind of enterprises usually find the bookkeeping company to complete the accounting treatment), or only a cashier, and cannot achieve the purpose of financial management.
Suggestions on financial management of private smes in Zhejiang province (figure 2) [5-8].

Strengthen cooperation with financial institutions, improve credit awareness, and solve financing problems through multiple channels. The difficulty of financing has always been the primary reason restricting the development of private small and medium enterprises. As the main body that needs financing, enterprises also need to make a difference in financing channels, that is, to enhance their competitiveness, determine market positioning, and continuously enhance their own accumulation capabilities and the ability to obtain external financing support. Secondly, the government must give full play to the role of macro-control, use policies, laws and economic means to promote the establishment and improvement of the credit guarantee system, which will help solve the financing guarantee problems of small and medium-sized enterprises more and more in the long run.

To improve the efficiency in the use of funds and produce the best results. To improve the efficiency in the use of funds and produce the best results. Improve the efficiency of capital use and produce the best results. In the financial activities of an enterprise, capital is an indisputable important factor in ensuring the normal operation and production of an enterprise. Only to ensure the normal operation of enterprises and improve their economic interests necessary: make a plan for the use of funds and optimize the allocation of funds; centralized management of funds.

Strengthen the financial consciousness of the whole staff. For private small and medium enterprises to achieve long-term and benign ecological development, enterprises need to strengthen financial management innovation and maximize the effectiveness of limited assets. Ideology is the key to influence people's behavior. The managers of enterprises need to pay attention from the ideological level. To effectively improve the financial awareness of financial personnel, enterprises must attach great importance to the improvement of the level of ideological education. 
Abandon traditional management way, adopt modern management method, innovate management way. In order to solve the innovation of corporate management ideas, companies need to absorb advanced management ideas at home and abroad, carry forward excellent local management ideas, and combine their own actual conditions to form a management structure with corporate characteristics to achieve corporate management innovation.

Make investment decisions more scientific and strive to reduce investment risks. Before investing in the project, enterprises should conduct feasibility study on the project, make correct decisions, avoid blind investment and try to reduce investment risks.

Rationally allocate financial staff according to the reality, and encourage them to update their professional knowledge.Enterprises should strengthen the education and training of financial management personnel and cultivate professional talents [8].

\section{CONCLUSION}

In summary, the operating and development environment of small and medium private enterprises in Zhejiang has undergone major changes. The financial management of private small and medium-sized enterprises is the foundation for the survival and development of enterprises. Small and medium private enterprises must actively adapt to changes and innovate financial management. Only by further strengthening financial management and optimizing the implementation of management measures can the scientific rationality of private small and medium enterprises in the market development be ensured. Enterprises need to pay attention to the importance of financial management innovation ideologically and continuously optimize financial management models.

At the same time, small and medium-sized enterprises actively adapt to the new requirements of the times, focus on innovating the financial management mechanism of small and medium-sized enterprises, and promote the informationization and precision of decision-making in small and medium-sized private enterprises.

\section{References:}

1. Wu Yajie (2019), "Discussion on the problems and countermeasures in the financial strategic management of small and medium-sized private enterprises", Enterprise Reform and Management, vol. 22, pp. 96- 102.

2. Zhang Qihui (2017), "Analysis on financial management problems of private small, medium and micro enterprises in Zhejiang province", Shopping Mall Modernization, vol. 24, pp. 125-126.

3. Hande Karadag (2015), "Financial management challenges in small and medium-sized enterprises: a strategic management approach", Emerging Markets Journal, vol. 5, pp. 25-40.

4. Wang Zhanxiang (2013), "Problems and countermeasures in financial management of private enterprises", Economic Research Guide, vol. 28, pp. 170-204.

5. Zhu Shaodong (2011), "Discussion on issues related to strengthening enterprise fund management", China Collective Economy, vol. 6, pp. 177-178.
6. He Xin (2018), "Importance and methods for financial staff to raise service Awareness", Fortune Today (Intellectual Property Rights in China), vol. 9, pp. 120.

7. Zhang Xuxia (2004), "Analysis on the current situation and countermeasures of financial management of private enterprises", Economic Forum, vol. 23, pp. $55-57$.

8. Ren Weijie and Cheng Lingli (2015), "Problems and countermeasures in financial management of small and medium-sized enterprises in China", Time Finance, vol. 26, pp. 178.

9. Yang Sijing and Zuo Qian (2011), "Analysis on the current situation of financial management in private enterprises and research on countermeasures", China Commerce and Trade, vol. 06, pp. 78-79.

10. Li Songlin (2017), "Discussion on the problems and countermeasures in the financial management of small and medium-sized enterprises", Science, Technology and Economy, vol. 30, pp. 179-181.

Стаття надійшла до редакчї 01.11.2020 p.

\section{Науково-практичний жсурнал} «ЕКОНОМІКА ТА ДЕРЖАВА»

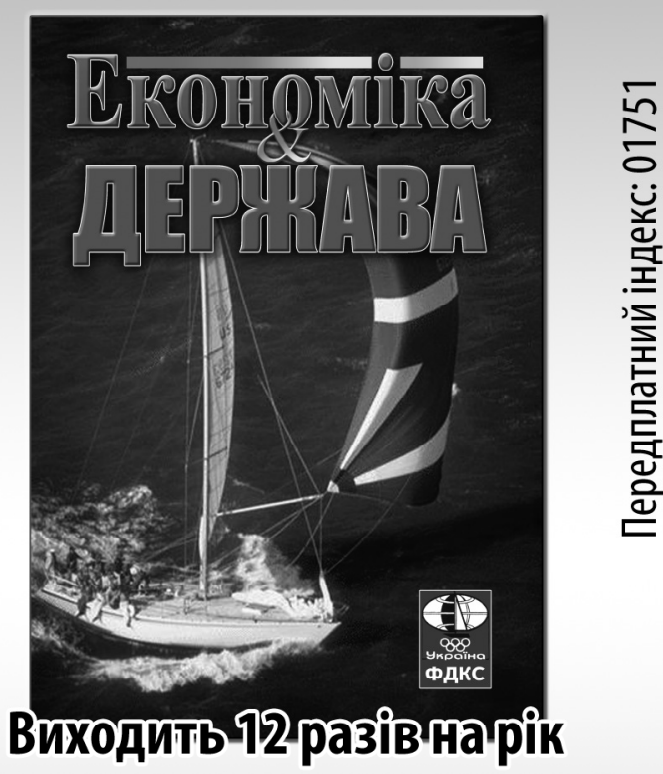

\section{наукове фахове видання України 3 ПИТАНЬ ЕКОНОМІКИ}

(Категорія «Б»)

Наказ Міністерства освіти і науки України від 28.12.2019 №1643

Спеціальності - 051, 071, 072, 073, 075, 076, 292.

www. economy.in.ua

e-mail: economy_2008@ukr.net

тел.: (044) 223-26-28

(044) $458-10-73$ 